\title{
Mendieta, Eduardo and Jonathan Vanantwerpen eds., The Power of Religion in the Public Sphere ${ }^{1}$
}

\section{Lukas Kaelin}

\section{$\mathrm{T}$} Thinking about religion in the public sphere is timely. The Arab Spring and the political turmoil in countries from Algeria to Bahrain give a new actuality to the question of the role of religion in the sphere of public deliberation. In this time of political transformation, questions arise about which role religion should play in the newly democratized countries of the Middle East. How does religion play out in public discussion and is represented in the newly drafted constitutions? Along with the crucial notion of civil society, the public sphere—as a sphere beyond family, state, and economy - is understood as the discursive infrastructure of a democratic society. The publication of the prominently casted volume, The Power of Religion in the Public Sphere in early 2011, bringing together the talks given at a conference in New York in October 2009, explores this renewed actuality. The four participants in this public discussion - Jürgen Habermas, Charles Taylor, Judith Butler, and Cornel West — are not only philosophers that leaped beyond their discipline, they are also paradigmatic models of public intellectuals. The volume consists of the papers of these four philosophers, the reprinted discussion between them and an afterword by Craig Calhoun.

Jürgen Habermas, in his opening paper, sets the stage in two regards: his seminal study, Structural Transformation of the Public Sphere (1989), still serves as the focal point of all discussions on the public spheres, and his recent turn towards religion as a moral resource for secular societies make him the paradigmatic expert in the field. His contribution challenges the notion of "the political" suggested by Carl Schmitt as a solution to the increasingly socially differentiated society with its technocratic momentum. However, to restore "the political" as the legitimating source of authority in the form of an authoritative figure is no longer akin to a secular, pluralist society. Habermas takes side with a Rawlsian model of liberal democracy and shares his demand for a translation of religious arguments into secular language. Habermas ends on the importance of this translation process and the use of religion as moral resource for secular societies.

${ }^{1}$ New York: Columbia University Press, 2011. 
The theoretical counterpoint, as it were, is set by Charles Taylor who suggests a "radical redefinition of secularism."2 Taylor, who has worked widely on the notions of modernity and secularism (most recently in his monumental A Secular Age published in 2007), claims that we cannot single out religion as a special case of reasoning. There are many different ways of reasoning and there is no such way as a neutral ground onto which all arguments in the public sphere can be adopted. The universalization of the epistemic break between reason and religion that Habermas shares with many others (most prominently Rawls) is part of the myths of the Enlightenment. Taylor does not deny the particular role of religion in the historical trajectory of Western societies but he sees that as a historical contingent relation. The neutral, secular ground suggested by Habermas is not that neutral after all.

Judith Butler's contribution is not directly on the philosophical question about the role of religion in the public sphere as such; rather she disentangles the different notions of "Judaism, Jewishness, and Zionism"3 and seeks to develop along a reading of Arendt, Benjamin, and Scholem a notion of Jewish dwelling as cohabitation. Edward Said's observation of an overlapping history of Jews and Palestinians in their essentially diasporic situation serves as witness, too. The diasporic situation is thus not understood in terms of its deficit and longing for a return to a specific homeland but rather as the demand of living in a plurality and of the acceptance of this situation of cohabitation as a given and the condition of every life on Earth. It is in the convergence of exiles where we experience our shared dependence and vulnerability, a model that might well serve as the basic understanding of the encounter in the public sphere. From this interpretation of Jewishness, Butler criticizes political Zionism and its attempt to create a homogeneous Jewish nation.

Butler's dwelling upon the messianic tradition of Jewish thought connects to Cornel West's prophetic speech on "the future of capitalist civilization."4 Rather than an analytic philosophical paper, West's speech challenges Plato's attempt to create a space for "love of wisdom" by delimiting it from poetry, a borderline that West likes at least to make porose: "philosophy must go to school with poetry." 5 In a very different way from Taylor, West stresses the unity of the human experience and calls for a mutual learning process between religious and secular people. Stressing the importance of listening to the other, the public sphere is implicitly conceived rather in a Bakhtinian way of a carnivalesque performance of one's ethical concerns in the daily practices than as a rational sphere of deliberation. It is West's moving rhetoric and his use of the public sphere to call attention to the most oppressed that triggered Habermas' comment in the following discussion that to

\footnotetext{
${ }^{2}$ Ibid., 34.

3 Ibid., 70.

${ }^{4}$ Ibid., 92.

${ }^{5}$ Ibid., 93.
} 
"continue academic discourse [after such a moving rhetoric] is somehow ridiculous."

The four papers are completed with a debate between Habermas and Taylor, one between Butler and West and a concluding discussion with all four participants. These debates allow a better grasp of the disagreements about the scope, functioning, and the limitation of the public sphere. In the discussion, the different perspectives of Habermas and Taylor on the role of religion - as a logic to be translated into secular language (Habermas) or as a comprehensive form of life among others (Taylor) — becomes evident. West's speech points to the way the public sphere is used in practice and how its rationality needs to be contextualized. Butler's particular focus on the Jewish question accentuates the religious potential as sources for (post-)secular societies and yet illustrates, again, the interrelatedness of religious and philosophical thought.

The book provides in a nutshell four divergent perspectives on the public sphere. All philosophers provide elsewhere more detailed accounts of their respective position on the issue; the anthology thus can serve as a mere starting point only to the question of the role of religion in the public sphere. A major asset of the book is the discussion part, which allows an insight into the actual working of public deliberation and pinpoints to the disagreements among major positions in the concept of the public sphere. A shortcoming in the volume consists in the remaining ambiguity about the concretion level of the discussion; different perspectives are provided but conceptual clarity is missed. The conceptual bracket of the volume of introduction and afterword puts the topic into a larger philosophical perspective. The volume thus serves as a stimulating introduction into a field of increasing importance in political philosophy.

Institut für Ethike und Recht in der Medizin, Universität Wien, Austria

${ }^{6}$ Ibid., 114 